\title{
Mining Industry Impact on Environmental Sustainability, Economic Growth, Social Interaction, and Public Health: An Application of Semi-Quantitative Mathematical Approach
}

\author{
Muhammad Mohsin ${ }^{1}\left(\mathbb{D}\right.$, , Qiang Zhu ${ }^{1}$, Sobia Naseem ${ }^{2, *}$, Muddassar Sarfraz ${ }^{3,4, *(D)}$ and Larisa Ivascu 4,5 \\ 1 School of Business, Hunan University of Humanities, Science and Technology, Loudi 417000, China; \\ mohsinlatifntu@gmail.com (M.M.); zhuqiang1968@126.com (Q.Z.) \\ 2 School of Economics and Management, Shijiazhuang Tiedao University, Shijiazhuang 050043, China \\ College of International Students, Wuxi University, Wuxi 214105, China \\ 4 Research Center for Engineering and Management, Politehnica University of Timisoara, \\ 300191 Timisoara, Romania; larisa.ivascu@upt.ro \\ 5 Faculty of Management in Production and Transportation, Politehnica University of Timisoara, \\ 300191 Timisoara, Romania \\ * Correspondence: Sobiasalamat@stdu.edu.cn (S.N.); muddassar.sarfraz@gmail.com (M.S.); \\ Tel.: +86-18751861057 (M.S.)
}

check for

updates

Citation: Mohsin, M.; Zhu, Q.;

Naseem, S.; Sarfraz, M.; Ivascu, L.

Mining Industry Impact on

Environmental Sustainability,

Economic Growth, Social Interaction, and Public Health: An Application of Semi-Quantitative Mathematical Approach. Processes 2021, 9, 972. https://doi.org/10.3390/pr9060972

Academic Editor: Esa Hämäläine

Received: 24 April 2021

Accepted: 20 May 2021

Published: 30 May 2021

Publisher's Note: MDPI stays neutral with regard to jurisdictional claims in published maps and institutional affiliations.

Copyright: (c) 2021 by the authors. Licensee MDPI, Basel, Switzerland. This article is an open access article distributed under the terms and conditions of the Creative Commons Attribution (CC BY) license (https:// creativecommons.org/licenses/by/ $4.0 /)$.

\begin{abstract}
The mining industry plays a significant role in economic growth and development. Coal is a viable renewable energy source with 185.175 billion deposits in Thar, which has not been deeply explored. Although coal is an energy source and contributes to economic development, it puts pressure on environmental sustainability. The current study investigates Sindh Engro coal mining's impact on environmental sustainability and human needs and interest. The Folchi and Phillips Environmental Sustainability Mathematics models are employed to measure environmental sustainability. The research findings demonstrated that Sindh Engro coal mining is potentially unsustainable for the environment. The toxic gases (methane, carbon dioxide, sulfur, etc.) are released during operational activities. The four significant environment spheres (atmosphere, hydrosphere, biosphere, and lithosphere) are negatively influenced by Thar coal mining. The second part of the analysis results shows that human needs and interests have a positive and significant relationship except for human health and safety with Sindh Engro coal mining. Environmental pollution can be controlled by utilizing environmentally friendly coal mining operations and technologies. Plantation and ecological normalization can protect the species, flora, and fauna of the Thar Desert. The government of Pakistan and the provincial government of Sind should strictly check the adaptation of environmental standards. Furthermore, the researchers should explore the environmental issues and solutions so that coal mining becomes a cost-efficient and environmental-friendly energy source in Pakistan.
\end{abstract}

Keywords: sindh engro coal mine; environmental sustainability; health and safety; social interaction and quality of life; economic development

\section{Introduction}

The rapid increase of coal exploitation and utilization declares that coal is a significant energy source. The contribution of coal energy to an individual country's economy cannot be denied, but coal mining distracts environmental sustainability. The regional and global coal mining areas are being influenced by incomplete combustion of carbonaceous fuels, i.e., Black Carbon. Black carbon is a solar radiation absorber and heats the earth-atmosphere system. Methane $\left(\mathrm{CH}_{4}\right)$ is abundantly released during the coal-mining process, and its leakage due to imperfect blockage methods, cracks, and vents in mines also facilitate to continue leaking outside. According to Environmental Impact Assessment (EIA), methane gas emissions during mining are $1 \%$ of total greenhouse gas emissions globally. Greenhouse 
(GHG) gas emission is a continuing problem in mining. According to Ohara, the Asian region increasingly contributes to GHG emissions [1]. The Regional Emission Inventory in Asia (REAS) was the first historical integration of present and future emissions in Asia by utilizing consistent techniques and methods. China inventory and emissions contribution are analyzed under three emission scenarios: Policy Success Case (PSC), Reference Case (REF), and Policy Failure Case (PFC). The total Asian emissions are affected by the contribution of China.

In China, the rapid emission is increased mainly due to coal combustion in the power plants and industrial sector. China mainly focused on production quantity while compromising on environmental sustainability. China will be able to decrease black carbon emission from 1.33 to $1.16 \mathrm{Tg}$ [2]. Pakistan is going to compromise on environmental sustainability because of the electricity crisis. The coal production and consumption boost other economic sectors/industries, i.e., power plants, cement industry, coke use, and brick kilns. Most industries utilized coal as a substitute for petroleum products, which became cost-efficient and profitable for sectors. The rapid growth in demand for energy for sectorial and domestic use encourage the exploration and utilization of the energy deposits. According to vision 2025, with Chinese companies' collaboration, Pakistan will be self-sufficient in the power sector, electricity demand and supply, coal efficiency, and power generation. The coal consumption is increased annually in Pakistan as $32.91 \%$ in $2015,3.57 \%$ in 2016, 23.92\% in 2017, and 60.75\% in 2018. Pakistan made a joint agreement with the China Pakistan Economic Corridor (CPEC) to minimize $\mathrm{CO}_{2}$ emission and clean coal technology to maintain the sustainability of the environment [3-5].

Almost all counties with ongoing coal mining processes are expected to have environmental sustainability issues and unnecessary emissions. The territorial analysis of Silesian counties based on the Prevalent Vulnerability Index scoring also confirmed a negative relationship between coal mining and ecological sustainability [6]. The special report of the Intergovernmental Panel on Climate Change (IPCC) 2018 on the impact of global warming stated that environmental health at $1.5^{\circ} \mathrm{C}$ above the preindustrial level could not be maintained. It has shown an underlined global intent and effort to reduce the global greenhouse emission by at least $45 \%$ until 2030 and brought it to be net-zero until $2050[7,8]$. Burke and Fishel [8] proposed the Coal Elimination Treaty (CET) to overcome greenhouse gas emissions and attain average global heating at $1.5^{\circ} \mathrm{C}$ before 2050. In his research, three negotiation pathways are presented with the inclusion of the inspirational normative model 2017 treaty on the prohibition of nuclear weapons. The primary focus is the progressive stigmatization, prohibition, and coal elimination to avoid an unmanageable climatic future.

Coal mining positively influenced Pakistan's economic development by contributing $13 \%$ of commercial energy consumption. Coal is an inexpensive energy source with 185.175 billion tons of deposits more than petroleum, oil, LPG, and LNG. The enhancement of energy and Pakistan's economy is continuously increasing by coal deposit utilization over the last ten years under the Alternative Energy Development Plan (AEDP), China Pakistan Economic Corridor (CPEC), Vision 2025, Vision 2035, and INDC development projects (Masih, 2018). Pakistan and China are collaboratively working on the coalfields, and Pakistan will install 8.4GW (capacity) coalfield power plants (CFPP) until the end of 2021. The expected contribution in GHG emissions by CFPP plants is $67 \%$ or $63.6 \mathrm{MT}$ [CO $\_2 \mathrm{a}^{-1}$. The scarcity of electricity generation sources in Pakistan compels burning coal to meet the needs of the population. These coalfield explorations and burning coal will increase the electricity supply from $0.1 \%$ to $16.5 \%$ in Pakistan until $2050[9,10]$. However, Pakistan is facing significant challenges in sustainable waste management in coal mining. The disposal methods of coal mining are not up to the standards of any developed country. This unsustainable waste management is seriously contributing to environmental degradation globally and domestically. Global GHG emissions must be substantially lowered for a sustainable environment. 
The Sindh Engro coalfield is the largest coalfield of Pakistan and considered one of the largest coal deposits (1.33 billion tonnes of coking coal) in a world that covers an area of 9000 KM2 approximately. As per the declaration of diagnostic macerals and petrographic, Thar coal is humic and predominantly features huminite with significant amounts of liptinite and low quantities of inertinite macerals. The Thar coal represents predominantly topogenous mires deposited under anaerobic conditions with limited thermal and oxidative tissue destruction. Coal mining near the residential area of Sindh has a prodigious impact on the environment, ecological habitats, society, and the country's economy. The global environment integrates the global living beings with their relationship with the atmosphere, hydrosphere, biosphere, and lithosphere. These four components of the environment enable us to cover all environmental sustainability areas. The open-pit coal mining's remediation of destruction has been the focus of several studies. Previous literature has considered the coalfields as an integral part of the global economy. Still, the greenhouse gas emission from coal mining has exceeded the remaining sectors of the global carbon budget $[2,9,11-13]$.

The environmental pollution level is increasing in Pakistan day by day. We keenly explored the particular directions of coal mining to get the facts about pollution hub to control the pollution as much as possible by using green ways of production. The research aims to explore the coal mining contribution to environmental pollution comprehensively. Pakistan has several coal ranges, but in this research, we used the Sindh Engro coal mine as a study sample. There are three fundamental reasons to select the Sindh Engro coalfield for this research: firstly, the Sindh Engro coalfield is the largest coal deposit area in Pakistan. Secondly, these coal deposits are mined with the collaboration of foreign companies as China. As per foreign interest, this coal range uses developed technology compared to other coal ranges. A developed technology user area suffers environmental issues, and the undeveloped or under-developed mining methods have more chance. As per the large deposit of coal in the Sindh coalfield, there is more chance of uptrend environmental pollution. If the facts and figures confirm the positive relationship between environmental pollution and coal mining, environmentalists can take practical steps to control it. The validity of this research and control methods will be checked quickly and applied to other coal ranges for attaining a better quality of the environment. The existing literature is generally based on air pollution, water pollution, and $\mathrm{CO}_{2}$ emission. Coal mining influences all spheres of the environment (atmosphere, biosphere, hydrosphere, and lithosphere), which we will explore individually in this research. The range of research from the perspective of the environment influencing factors is comparatively wider than the existing coal mining literature.

\section{Study Background}

\subsection{Coal Mining and Atmosphere}

The earth's atmosphere is barricaded by the layer of gases known as air. The atmosphere retained the gravity of the earth and formatting the planetary surroundings. The specific pressure of air for liquid water on the earth's surface, absorption of toxic and ultraviolet radiations, heat retention, and normalization of diurnal temperature variation are controlled by the atmosphere to protect earth habitants. The suspended particular matters (SPM) and respirable particulate matter (RPM) of air pollution are observed in the air of coal mine surroundings as well as projected areas [14]. The air contains different gases at a specific level for healthy atmosphere equilibrium. In this era of development, the atmosphere's equilibrium has changed, and humans also contributed to this change by industrialization, mining, and environmentally opposed technology. The coal mining process and burning coal emit particulates, arsenic, and carbon dioxide $[15,16]$. The environment influences underground mining by reducing methane $\left(\mathrm{CH}_{4}\right)$, which is growing faster than carbon dioxide. The deeper coal mines contain a higher amount of methane $\left(\mathrm{CH}_{4}\right)$ deposits. During mining operational activities, methane gas is released into the air and becomes part of the atmosphere. The gas emission in operation and combustion coal become the reason for pillar collapse and roof falling. Mining operational and structural 
flaws also generate acidic mine drainage. The mine pillars cover large surface areas and the slow oxidation of a sulfur compound by exposure to air. The dumped sludge and wastes of the coal mining operation also increase the toxic effect under the surface. The sulfur oxidation compounds leaching of the resultant acid in surface dumps, creating a risk of rainwater percolating. The pyrite reaction with air and water with sulfuric acid then generates Acid Mine Discharge (AMD). The analytical part of this study is based on two parts: qualitative part (Folchi method) and quantitative part (Phillips Environmental Sustainability Mathematics (PESM) Model). Due to a combination of qualitative and quantitative features, this research confirmed its semi-quantitative quality. The Folchi method covered almost all environment influenced factors as per four significant spheres of environment, i.e., atmosphere, biosphere, hydrosphere, and lithosphere. Table 1 presented all possible coal mining environments and impacting factors specification. Table 2 contains the numbering according to the intensity of influencing factors for the indexing process. This table also explains the measuring scale of the individual factor for the convenience of readers. Table 3 is most important to understand for interlinking before and after processes. Table 3 is technically maintained with possible maximum, medium, and minimum points by Folchi. The values from Table 2 as per the contribution scale of environmental factors are multiplied with Table 3 , and the result of the multiplication is Table 4 . The aggregate scores of an individual factor in Table 4 declared the actual contribution of these factors in the environment for the Sindh Engro coalfield. The first qualitative part and indexing are completed. The second part, the Phillips Environmental Sustainability Mathematics (PESM) Model, is started. The expected scores and actual scores are put in the Phillips Environmental Sustainability Mathematics formula. The final figure decides the sustainable or unsustainable contribution of coal mining in environmental sustainability. As per our analysis, the Environmental contribution is less than Human needs and interests. The Sindh Engro coal mines confirmed an unsustainable relationship with the environment. The Sindh Engro coal mines have the largest deposit of coal and explore coal with foreign collaboration. Due to foreign association to digging coal, this coalfield utilized well-developed technology to explore the coal deposits. The unsustainable environmental contribution can ease the way to explore less developed coal mines and eradicate the emissions-friendly resources that will enable the sustainable contribution in the environment and economy.

The dissolution of acids and heavy metals, i.e., copper, lead, and mercury, in-ground or surface water, have an acidic reaction with soil.

Table 1. Mining environment categories and impact factors.

\begin{tabular}{ccc}
\hline Sr. No. & Coal Mining Environment & Coal Mining Impacting Factors \\
\hline 1 & Health and safety of human & Land dispossession and potential resources \\
2 & Social interaction and quality of life & Exposition, visibility of the pit \\
3 & Water pollution & Above-ground water pollution/depletion \\
4 & Air pollution & Underground water pollution/depletion \\
5 & Soil Erosion & Increase in vehicular traffic \\
6 & Biodiversity loss & Atmospheric release of gas and coal dust \\
7 & Above-ground interferences & Mine tailing spills \\
8 & Underground interferences & Level of noise \\
9 & Aesthetic degradation & Vibration of ground \\
10 & Noise pollution & The livelihood of the local workforce \\
11 & Economy & Contribution in GDP \\
\hline
\end{tabular}


Table 2. The magnitude of impacting factors.

\begin{tabular}{|c|c|c|}
\hline Impacting Factors & Scenario & Magnitude \\
\hline \multirow{4}{*}{ Land dispossession and potential resources } & Parks, protected areas & $8-10$ \\
\hline & Urban/rural area & $6-8$ \\
\hline & wildlife, agro-diversity & $3-6$ \\
\hline & Industrial area & $1-3$ \\
\hline \multirow{3}{*}{ Exposition, visibility of the pit } & Can be seen from inhabited areas & $6-10$ \\
\hline & Can be seen from the main roads & $2-6$ \\
\hline & Not visible & $1-2$ \\
\hline \multirow{3}{*}{ Underground water pollution/depletion } & Interference with lakes and rivers & $6-10$ \\
\hline & Interferences with the non-relevant water system & $3-6$ \\
\hline & No interference & $1-3$ \\
\hline \multirow{3}{*}{ Above-ground water pollution/depletion } & $\begin{array}{l}\text { Surface water pollution/Decreasing water } \\
\text { (physicochemical, biological) quality }\end{array}$ & $5-10$ \\
\hline & Water table deep and permeable grounds & $2-5$ \\
\hline & Water table deep and unpermeable grounds & $1-2$ \\
\hline \multirow{3}{*}{ Increase in vehicular traffic } & Increase of $200 \%$ & $6-10$ \\
\hline & Increase of $100 \%$ & $3-6$ \\
\hline & No interference & $1-3$ \\
\hline \multirow[t]{3}{*}{ Atmospheric release of gas and coal dust } & Free emissions in the atmosphere & $7-10$ \\
\hline & Emission around the given reference values & $2-7$ \\
\hline & Emission well below the given reference values & $1-2$ \\
\hline \multirow{4}{*}{ Mine tailing spills } & Toxic gases releasing during process & \\
\hline & No blast design and no clearance procedures & $9-10$ \\
\hline & Blast design and no clearance procedures & $4-9$ \\
\hline & Blast design and clearance procedures & $1-4$ \\
\hline \multirow{3}{*}{ Level of noise } & $<141 \mathrm{db}$ & $8-10$ \\
\hline & $<131 \mathrm{db}$ & $4-8$ \\
\hline & $<121 \mathrm{db}$. & $1-4$ \\
\hline \multirow{2}{*}{ Vibration of ground } & Cosmetic damage, above threshold & $7-10$ \\
\hline & Tolerability threshold & $3-7$ \\
\hline \multirow{5}{*}{ The livelihood of local workforce } & Values under tolerability threshold & $1-3$ \\
\hline & Job opportunities & \\
\hline & High & $7-10$ \\
\hline & Medium & $3-6$ \\
\hline & Low & $1-2$ \\
\hline \multirow[t]{4}{*}{ Contribution in GDP } & Level of GDP contribution & \\
\hline & High & $7-10$ \\
\hline & Medium & $3-6$ \\
\hline & Low & $1-2$ \\
\hline
\end{tabular}


Table 3. The correlation matrix of impacting factors and component magnitude.

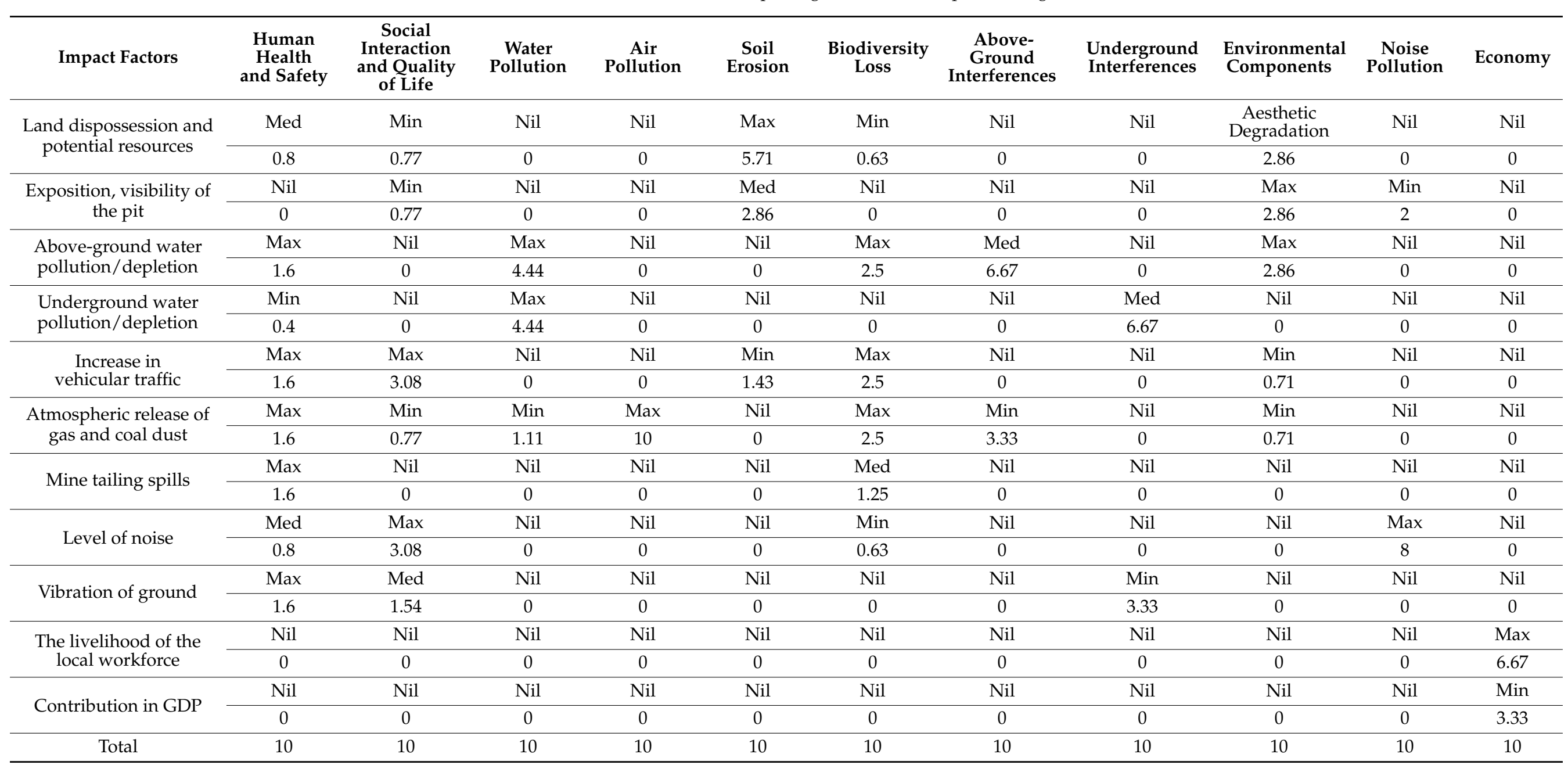


Table 4. Final weighted impact scores of Sindh Engro coal mining.

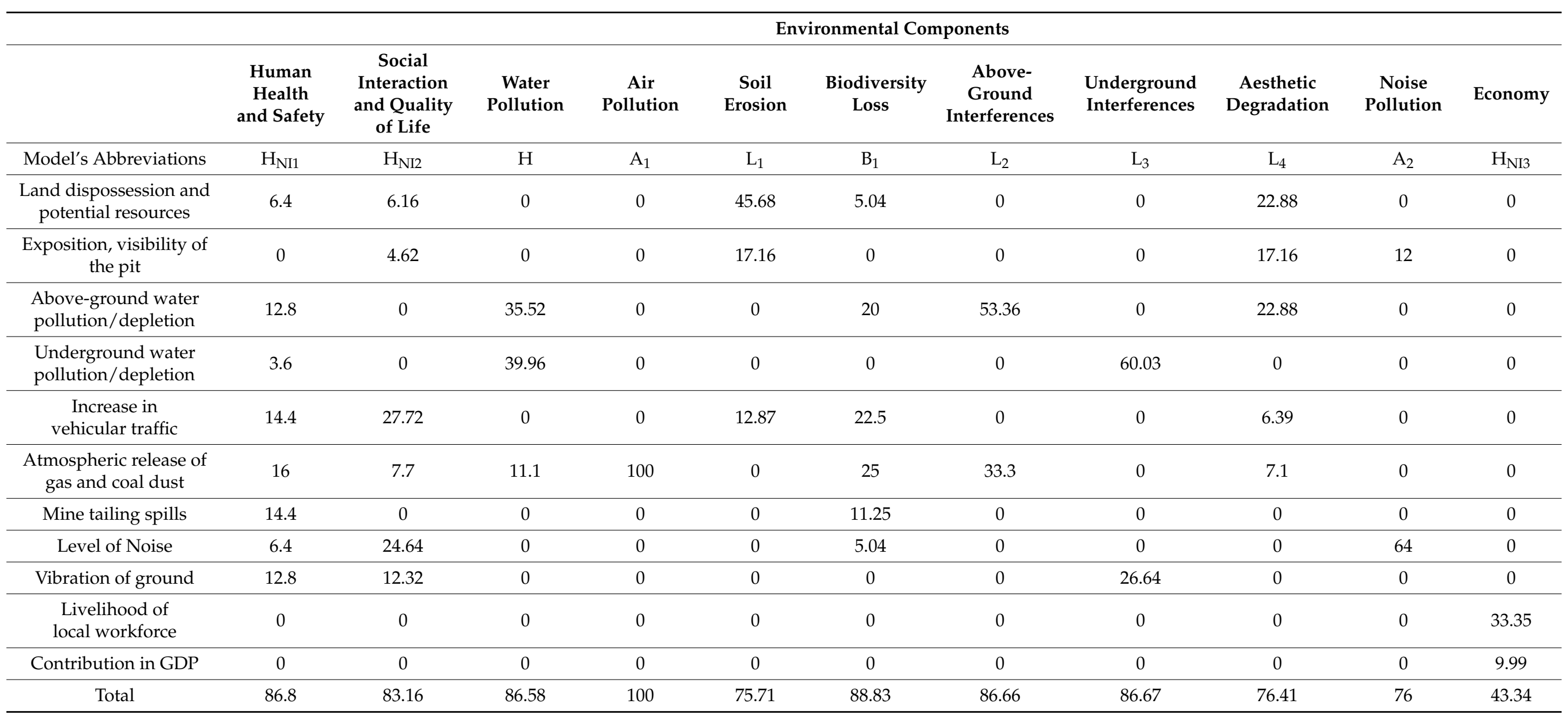




\subsection{Coal Mining Impact on Biosphere}

The local biodiversity suffers tremendous pressure from mining activities. The coal mining activities endangered the habitats and necessary ecosystem. The persistence and bio-accumulative nature of living beings is extremely endangered by potentially toxic elements (PTEs) with their toxic contamination and pollution $[17,18]$. The potentially toxic elements (PTEs) threatened the natural ecosystem by weathering and eroding parent rocks and ore deposits while susceptible anthropology by waste or tailing deposits, agrochemical, and industrial effluents. The discharging processes of potentially toxic elements in the ecosystem are mobilized by physicochemical and microbial factors, passing through divergent environmental cubicles $[19,20]$. The Indigofera, Indigofera oblongifolia, Indigofera argentea, Aristida funiculate, Convolvulus portraits, Cassia Italica, Dipterygium glaucum, and Digera ardencies, while plant communities Aerva javanica, Calligonum polygon sides, and Leptadenia pyrotechnica species are endangered due to the intensive environment of Thar. Animal grazed these plants at the pre-and post-monsoon periods when the ephemerals were not available due to the drought period. To protect these species, environmental sustainability with appropriate environmental conditions is necessary. Shortage of water resources, grazing trees, and plants is also an alarming situation for 35 mammalian fauna of Thar Pakistan. According to a wildlife ecologist report, Indian wild ass (Equus hemionus), Striped hyaena (Hyaena hyaena), chinkara (Gazella bennettii), and nilgai or blue bull (Boselaphus tragocamelus) are near threatened. The species are endangered due to Thar coal power projects and coal mining operations [21-23].

\subsection{Coal Mining Impact on Hydrosphere}

Mine excavation possesses water influx by rainfall or interception of groundwater flows. The minor portion of this water is used for processing and dust suppression and remaining pumped out due to its unwanted mining feature. The unwanted water feature is contaminated by particulate matter, oil and grease, un-burnt explosives, and other chemicals. The high rate of pyrites in coal indicates the toxic and acidic water that can affect the water resources by discharging it into nearby streams [24]. Whether under or above the earth's surface, the combined mass of water is known as the hydrosphere. The hydrosphere layer is disturbing by polluted and environmentally unfriendly human beings' activities. Mining is one activity that will unstabilize the water quality and increase water pollution. The underground and above groundwater resources significantly affect the irrigation system due to metal concentration in crops and soils. The increasing metal association level, metal partitioning, soil-to-plant bio-concentration factor (BCF), and gas concentration caused severe health issues by vegetable ingestion $[7,17]$. Severe pollution is observed in nearby streams, water, soil, and the cultivated crops over the coal mining area. By employing organic geochemical and petrographic analyses on critical petrographic facies and diagnostic macerals, the coal seams in Thar coalfield, coal rank, and hydrocarbon generation potential belong to predominant type III kerogen (gas-prone) grading into mixed types II-III kerogens (oil and gas-prone). The microscopic observation declared organic matter in Thar coal, which is dominated by huminite (woody) with a significant amount of oil-prone liptinite macerals and low inertinite macerals. The Tissue Preservation Index (TPI) and high Gelification Index (GI) demonstrated the consistency of marsh-wet forest swamp freshwater environment and limnotelmatic conditions.

\subsection{Coal Mining Impact on Lithosphere}

The lithosphere of the earth is composed of the crust, and the upper mental portion of it behaves elastically on time scales. The surface's mineralogy and chemistry are distinguished between the crust and upper mental. The mines and minerals belong to the continental crust with layers of igneous, sedimentary, and metamorphic rocks $[24,25]$. Soil erosion, inner and outer interferences, and land/aesthetic degradation are part of it. Soil erosion and land degradation primarily lead the topsoil and organic matter loss. The topsoil and organic matter are fundamental ingredients of planting. Generally, water, wind, 
and mass movements play a significant role to move soil erosion. Climate change is a key factor of global soil erosion degradation. The suitable conditions of soil erosion are rainfall (frequency, duration, and intensity), winds (level of intensity, directions of wind and frequency), and water (underground and above ground). The Thar coal mining areas fulfill all the soil erosion conditions, which negatively affect environmental sustainability. Natural geotextile formulating by organic material is more effective and beneficial to reduce soil erosion in working stations. In the last two decades, soil erosion, soil degradation, soil loss, and soil pollution are increasing, and environmental pollution accelerates it. The mineral process wastages, industrial wastages, and the pollution created by human activities contributed to it [26,27].

\subsection{Human Needs and Interest and Coal Mining}

\subsubsection{Health and Safety of Human}

The coal cutting, excavation, and transportation in the coal-mining field are involved in fatalities, injuries, and disease risk. The underground mining occupation is considered the most dangerous job, which becomes the reason for respiratory diseases such as infected lungs, skin allergy, deafness, heart burning, and psychological stress among the workers [28-30]. The poisonous gas hydrogen sulfide emits during coal mining, and its longer-term exposure caused eye irritates, headache, fatigue, lungs, and respiratory tract. The operational coal dust with toxic gases and improper management of wastages creates permanent health hazards for workers and the residential community [31,32]. Paul and Maiti [20] further explained that minors' behavioral motivation also affected the rate of accidents/injuries. By utilizing behavioral safety analysis on two neighboring coal mines of India, it is observed that the accident group of workers was dissatisfied with their job, which negatively influenced and risk alarming. The job dissatisfaction urges the worker to take more risk on the working station and behave unsafely. Panhwar confirmed the risk of health and safety in coal mining using the convenience sampling method and a structured questionnaire [33]. Panhwar et al. [30] approached 97 mines workers for data collection via a structured questionnaire regarding the work environment, physical health of miners, and protection policies of mines. According to the last five years, there were 4 deaths by roof falling, 1 death by stone fall down from mine shaft, 3 fatalities due to suffocation and inhaling toxic gases, 121 injuries by different accidents, and 1 causality through rope haulage pulley in Lakhra Coal Mines. The maximum health and safety risk is triggering because of a lack of awareness about labor law and mining laws in developing countries. According to the compliance law of mining in Pakistan, appropriate working conditions is compulsory for every worker. The mining workers generally belong to backward areas and are not well-educated, so they are deprived of full awareness about health and safety. The workers' unawareness leads to continuous fatalities and safety issues. The mining workers do not adequately get safety training before joining the job. The rate of causalities and accidents is higher for inexperienced and untrained workers than experienced workers [12,32,33]. The contaminated water is used as drinking water at the working station due to potable fresh water's unavailability. The hygiene and bad odor problems also occur because the proper toilets are not available at operational places [34-36].

\subsubsection{Social Interaction and Quality of Life}

The major development projects with lower environmental risk and higher social/ economic contribution are considered beneficial for people. Pakistan is immediately trying to overcome energy crises, and achieving this goal, coal energy is exploited. Thar coal is mainly used to minimize the pressure of energy crises, while this project contributes to the development of Thar by generating new job opportunities. However, some social issues transpired in relation to Thar coal during a survey of the ground realities, interaction with Sindh Engro Coal Mining Company (SECMC) officials, and concerning villagers. The major concerns of society or the residents of Thar are the dumping or disposal of mining wastages. The villagers protest against the Gorano pond/dam construction to collect water 
waste and mines effluent. The coal mining activities have started in some blocks, and some are still untouched. The Gordano pond/dam can receive block II wastages and effluents, so how will the other blocks' effluents be disposed of after actively working with them? The construction of ponds for every mining block can destroy the soil quality, water quality, and environmental sustainability of Thar. No doubt, Thar coal mining contributes to social development. Simultaneously, constructing and ponding Gorano dam with saline water creates problems for ecology, morphology, biodiversity, hydrology, soil composition, and environmental sustainability.

\section{Materials and Methods}

\subsection{Site Description}

Pakistan has started to dig up the world's largest coal deposit in the Thar Desert with Chinese companies' collaboration. The Thar Desert coal station is located in the Mithi region, Tharparkar District, Sindh province of Pakistan (see Figure 1). This research has used Sindh Engro Coal Mining, Thar Desert, Pakistan, as a sample. This is a joint venture between Sindh and Engro Corporation's government, while Chinese Machinery Engineering Corporation is also part of this coal-mining project. The Thar Desert's mining coal is low-grade, brown, dirty coal known as lignite coal. The coal mining area is based on a rural community of almost 12 villages. The detailed operational activity in Thar Desert coal mining and an ariel view of the EPTL power plant in Thar are presented in Figures 2 and 3.
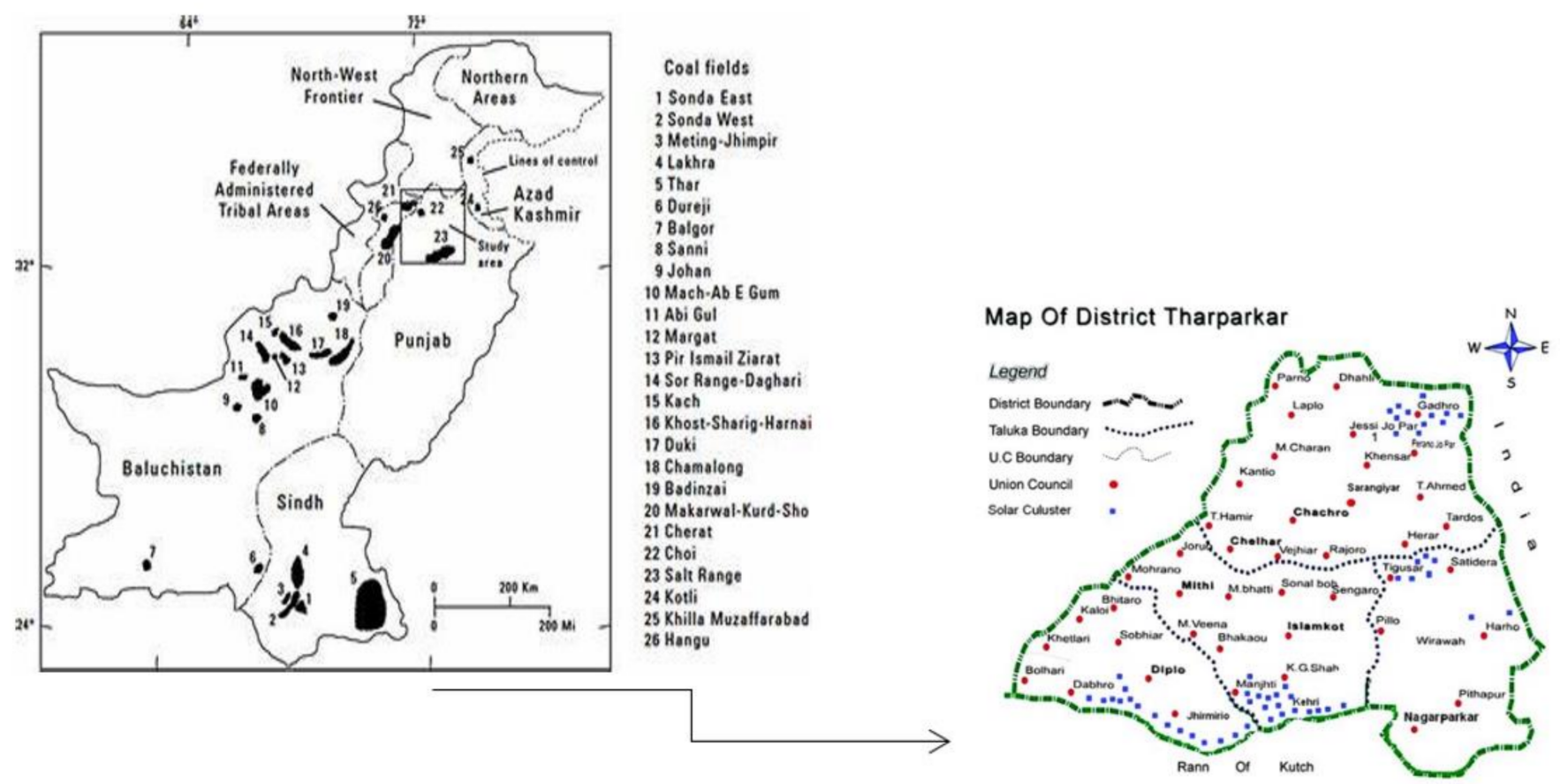

Figure 1. Coal fields in Pakistan and detailed map of district Tharparker. 


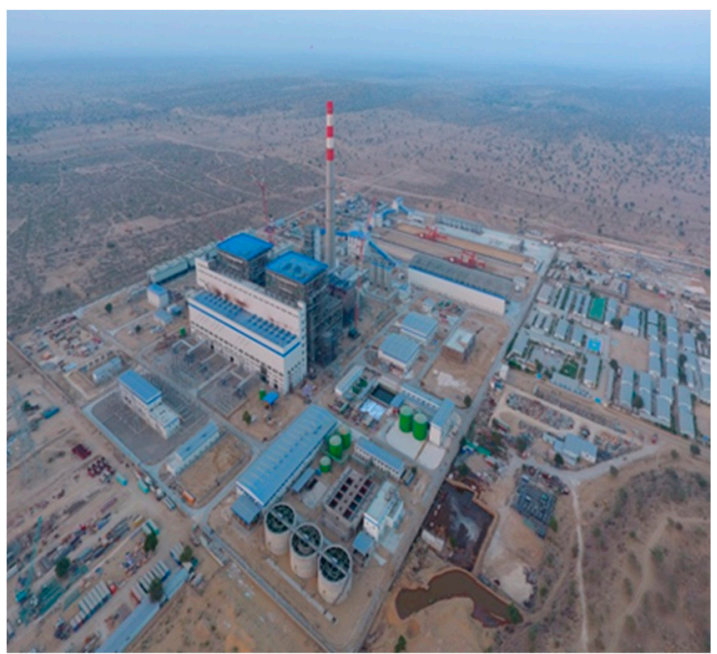

Figure 2. An ariel view of EPTL power plant in Thar.

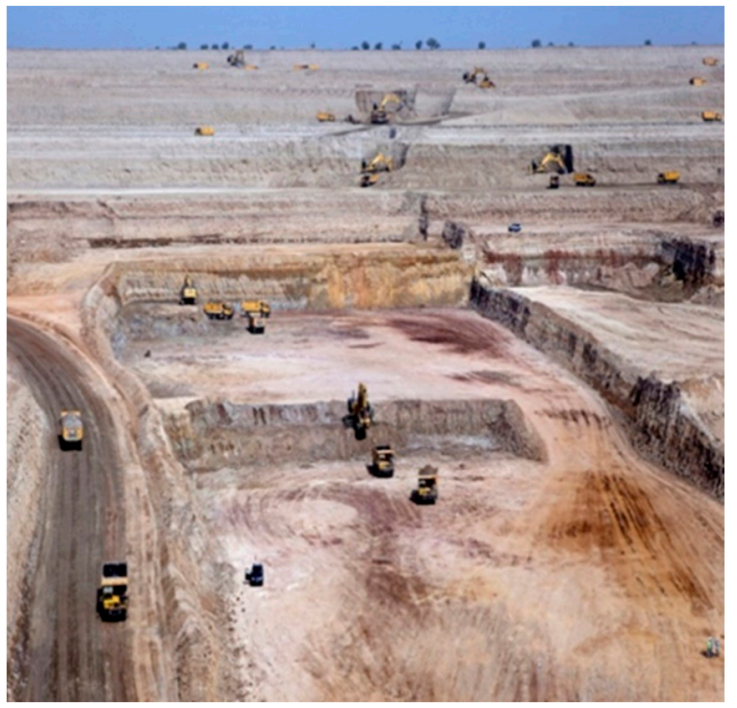

Figure 3. Operation at the Sindh Engro Coal Mining Company site in Thar Desert (source: Bloomberg).

\subsection{Methodology}

The current study research methodology is based on the Folchi method for environmental factorization and indexing, while the second is based on the Phillips Environmental Sustainability Mathematics (PESM) Model. In addition, the Folchi method has been used in PESM for data analysis.

\subsubsection{Folchi Method}

The Folchi method is technically designed for quantifying the impact of mining on the environment by operational activities (drilling, blasting, and collecting minerals). Previous studies confirm the accuracy of the analysis, but data analysis accuracy can be gained if the authorized personnel collect it [37,38].

The coal mining environment and factors affecting it are listed as presented in Table 1. The first column consists of coal mining environment categories, and the second column contains coal mining impacting factors. As per mining operation, all possible environmental factors are covered in it. In Figure 4, the Folchi method's step-by-step process is presented for a quick process visual. 


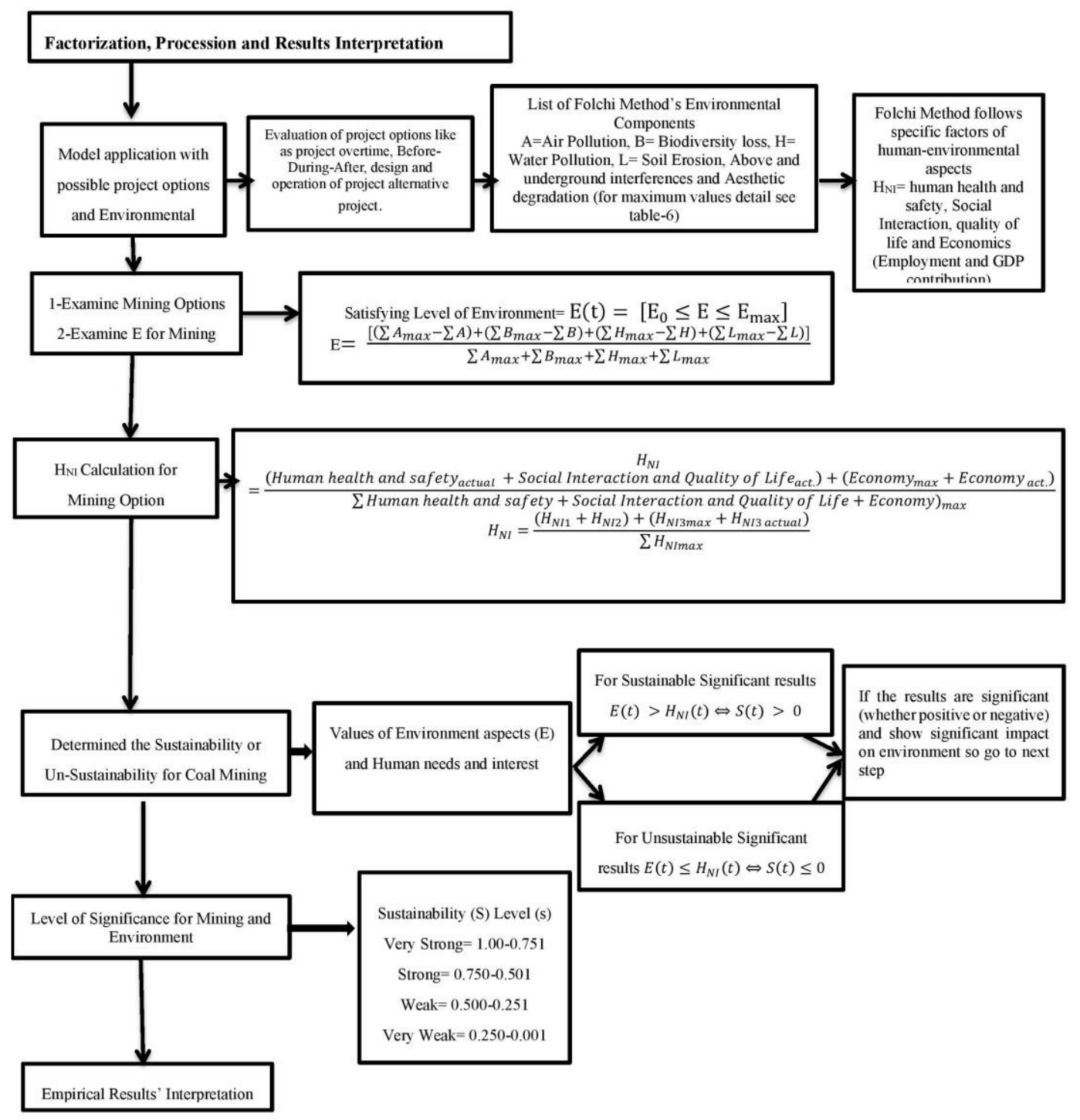

Figure 4. The successive steps of the Folchi Method for measuring environmental sustainability.

Table 2 shows the magnitude of environmental, social, and economic factors. The expected ranges of impacting factors are defined, i.e., intensive impact, medium impact, and low impact. The scores are allotted according to the actual contribution of the factor in the environment. Information will be collected of minors of the Sindh Engro coal mine and residential areas of it.

The correlation matrix of affecting factors and magnitude of components is presented in Table 3. The correlation matrix replicates the endangered level and contribution of environmental factors. The possible contribution of the individual category or factor is divided into three portions, i.e., Maximum (Max), Med (Median), and Minimum (Min). The category and content with no significant relationships or irrelevant are mentioned with zero (Nil) in Table 3. The possible contribution of individual category or factor is divided into three portions, i.e., Maximum (Max), Med (Median), and Minimum (Min). The category and content with no significant relationships or irrelevant are mentioned with zero (Nil) in Table 3.

\subsubsection{Phillips Environmental Sustainability Mathematics (PESM) Model}

The mathematical model of Phillips is used to examine the sustainable or unsustainable effect of coal mining on the environment by using magnitude recognition values of Folchi. 
The model has two parts, i.e., environment and human needs $[38,39]$. The environmental contribution is measured by following Equation (1):

$$
\begin{gathered}
\mathrm{E}=\frac{\left[\left(\sum \mathrm{A}_{\max }-\left(\mathrm{A}_{1}+\mathrm{A}_{2}\right)+\left(\sum \mathrm{B}_{\max }-\sum \mathrm{B}\right)+\left(\sum \mathrm{H}_{\max }-\sum \mathrm{H}\right)+\left(\sum \mathrm{L}_{\max }-\left(\mathrm{L}_{1}+\mathrm{L}_{2}+\mathrm{L}_{3}+\mathrm{L}_{4}\right)\right]\right.\right.}{\sum \mathrm{A}_{\max }+\sum \mathrm{B}_{\max }+\sum \mathrm{H}_{\max }+\sum \mathrm{L}_{\max }} \\
\mathrm{E}=\frac{\left[\left(\sum \mathrm{A}_{\max }-\sum \mathrm{A}\right)+\left(\sum \mathrm{B}_{\max }-\sum \mathrm{B}\right)+\left(\sum \mathrm{H}_{\max }-\sum \mathrm{H}\right)+\left(\sum \mathrm{L}_{\max }-\sum \mathrm{L}\right)\right]}{\sum \mathrm{A}_{\max }+\sum \mathrm{B}_{\max }+\sum \mathrm{H}_{\max }+\sum \mathrm{L}_{\max }} \quad E Q-1 .
\end{gathered}
$$

In the above equation, four main parts of the environment $\mathrm{E}(\mathrm{t})=(\mathrm{A}+\mathrm{B}+\mathrm{H}+\mathrm{L})$ are indicated with different abbreviations: " $\mathrm{A}$ " for Atmosphere, " $\mathrm{B}$ " for Biosphere, " $\mathrm{H}$ " for Hydrosphere, and " $\mathrm{L}$ for Lithosphere. The fluctuation of spheres is measured concerning time. The maximum safe environmental anthropology system with its maximum limits and sub-spherical operation is examined by $\mathrm{E}(\mathrm{t})=\left[\mathrm{E}_{0} \leq \mathrm{E} \leq \mathrm{E}_{\max }\right]$. $\mathrm{E}$ denotes the spherical progression, adaptation, renewal, and repairing environment concerning time $t$. The level of the environment is calculated as $E=\frac{\mathrm{E}_{\max }-\sum \mathrm{E}}{\sum \mathrm{E}_{\max }}$; the actual contribution of environmental factors is deducted from maximum environmental value and divided by the maximum value of the environment.

The second part of the model is a human need, which presented below in Equation (2):

$$
\begin{gathered}
\mathrm{H}_{\mathrm{NI}}=\frac{\left(\mathrm{H}_{\mathrm{NI} 1}+\mathrm{H}_{\mathrm{NI} 2}\right)+\left(\mathrm{H}_{\mathrm{NI} 3 \max }-\mathrm{H}_{\mathrm{NI} 3 \text { actual }}\right)}{\sum \mathrm{H}_{\mathrm{NImax}}} \\
\mathrm{H}_{\mathrm{NI}}=\frac{\left(\sum \mathrm{H}_{\mathrm{NImax}}-\sum \mathrm{H}_{\mathrm{NI}}\right)}{\sum \mathrm{H}_{\mathrm{NImax}}}
\end{gathered}
$$

In Equation (2), $\mathrm{H}_{\mathrm{NI}}$ covers human needs or socio-economic factors, i.e., the collection of (Human Health and Safety + Social Interaction and Quality of Life + Economy), $\mathrm{H}_{\mathrm{NI1}}, \mathrm{H}_{\mathrm{NI2}}, \mathrm{H}_{\mathrm{NI3}}$ indicate three components, respectively. The human needs components $\mathrm{H}_{\mathrm{NI}}(\mathrm{t})=\left[\mathrm{H}_{\mathrm{NI}} \leq \mathrm{H}_{\mathrm{NI}} \leq \mathrm{H}_{\mathrm{NI}} \max \right]$ indicate the resources and environmental contribution for human life and survival.

After calculating the environmental and socio-economic factors, the next process is to check the relationship between environment, socio-economic conditions, and coal mining in Sindh. This model's last step elucidated the viable working environment and sustainability level in coal mining. To determine sustainability, the calculated human interest and needs value is deducted from the calculated environmental value $\mathrm{S}(\mathrm{t})=\mathrm{E}(\mathrm{t})-\mathrm{H}_{\mathrm{NI}}(\mathrm{t})$. If $\mathrm{E}(\mathrm{t})>\mathrm{H}_{\mathrm{NI}}(\mathrm{t}) \Leftrightarrow \mathrm{S}(\mathrm{t})>0$, so the sustainable and positive impact on the environment will be declared. If $\mathrm{E}(\mathrm{t}) \leq \mathrm{H}_{\mathrm{NI}}(\mathrm{t}) \Leftrightarrow \mathrm{S}(\mathrm{t}) \leq 0$, a negative and unsustainable impact on the environment will be declared.

\section{Results}

The coal mines are used to select individual environmental components' specific magnitude. As per the Folchi method's assumption, the maximum score of the individual component is 100 . The actual weightage of affecting determinants declares the individual contribution to environmental sustainability. Table 3 is generated by multiplying each individual factor's magnitude and correlation matrix (see Figure 5). The first factor, land dispossession and potential resources, received 8 points because the Sindh Engro coal mining area is in the Mithi region's rural areas. The affected population of Sindh Engro coal mining is 12 villages. The exposition and visibility of the pit received 6 points as per its magnitude. The open-pit area can be seen from the road easily. The water pollution and resources of underground and above-ground received 8 and 9 points, respectively. 


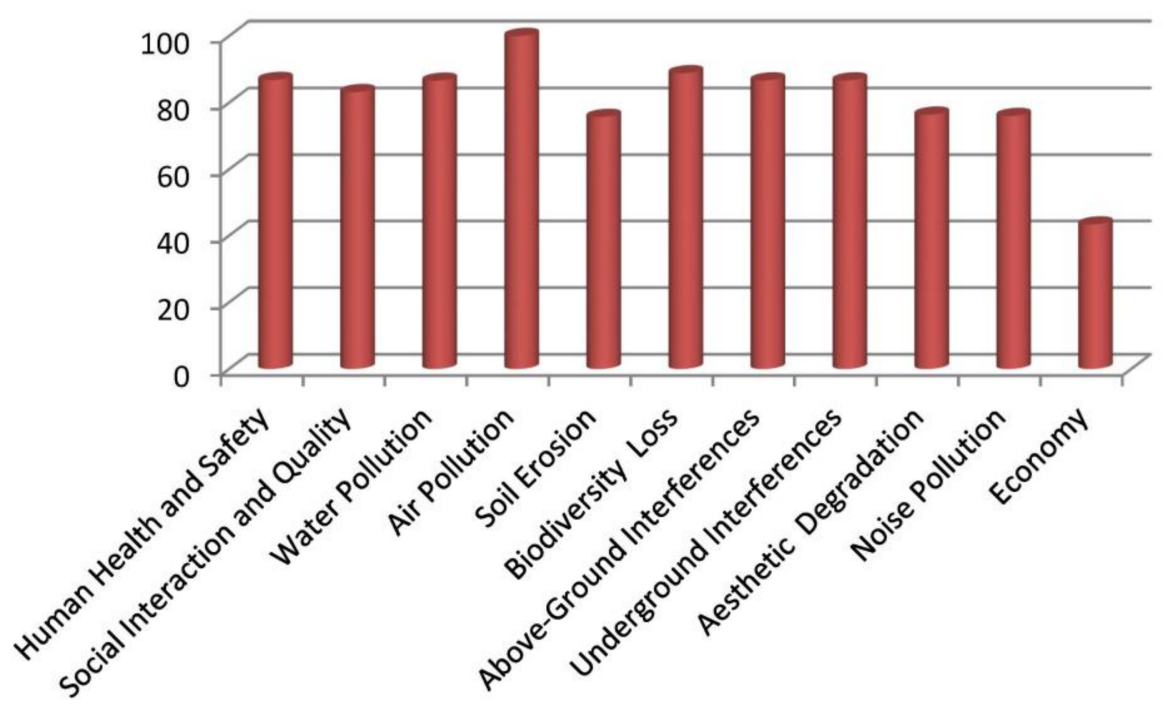

Figure 5. Final weighted impact scores of Sindh Engro coal mining.

The coal mine has affected surface water, facing physicochemical and biological issues. The coal mining exposed rocks containing high sulfur-bearing mineral pyrite and dissolved it with water wash to attain the coal. The sulfur-bearing mineral pyrite reacts with water and air and becomes the reason for acidic water outflow. This compounded form of dilute acid is in nearby rivers, lakes, and streams. The quality of water, underground, and aboveground resources directly endangered human life by its processed, acidic mine drainage and coal sludge refinery process. The coal mining started at Sindh Engro coal mining station in 2015, and the traffic rate increased by $200 \%$ due to mining. The increase in vehicle traffic attained 9 points as per its increasing level. Coal mining strongly contributes to the atmospheric release of gases and coal dust, while 10 points are allotted because of the free emission of toxic gases [38-40].

Coal mining diffuses sulfur dioxide $\left(\mathrm{SO}_{2}\right)$, nitrogen oxide $\left(\mathrm{NO}_{2}\right)$, methane $\left(\mathrm{CH}_{4}\right)$, carbon dioxide $\left(\mathrm{CO}_{2}\right)$, particulate matter (PM2.5, PM10), and heavy metals in the air. The diffusion of toxic gases and coal dust increases smog, acidic rains, and deadly respiratory, cardiovascular, and cerebrovascular issues. The mine tailing spill attained 9 points because of the design blast and no clearance procedure. The minerals are mined, and due to a lack of resources, the wastages are not disposed of appropriately. The coal fire generally happens during coal mining and coal wastage, so coal fire emits mercury and $\mathrm{CO}_{2}$. The local environment is facing toxic air, water, and rains due to the mine-tailing spill. The wastage of the mining process disposed of in surface impoundments affected the land's internal and external surface by leaching out the toxic metals [41-43].

The working station's level of noise is between 131 and 141 decibels (DB). That is why the magnitude table allotted 8 points to the noise level. According to the noise chart, the heavy traffic, machinery, and blasting voice are between 131 and 141 decibel levels. The ground vibration received 8 points because of cosmetic damages above the threshold. The working station is in vibrating mode during operation, and the vibration is intense, which can affect minors' body organs. The last two components are related to the economy, i.e., the livelihood of local forces and contribution to GDP. The weightage of local details' livelihood is five because of the medium employment level of residents. The Chinese Engineering Company invested in this mining project, so the engineering team is not local.

The contribution in GDP received 3 points because of low contribution. The Sindh Engro Coal mine is not fully explored yet; it is in the working process. After the multiplication of assigned points to individual component and correlation matrix, the total points of human health and safety, social interaction and quality of life, water pollution, air pollution, soil erosion, biodiversity loss, above-ground interferences, underground interferences, aesthetic degradation, noise pollution, and economy are 86.8, 83.16, 86.58, 100, 75.71, 88.83, 
$86.66,86.67,76.41,76$, and 43.34 respectively. The individual category's summation is used in the Phillips Environmental Sustainability Mathematics (PESM) model to measure the sustainable or unsustainable relationship between coal mining and environmental sustainability.

Table 5 contains the abbreviation of categories and the maximum weightage of individual categories. As per methodological explanation, the modeling covers two main affected areas of coal mining, i.e., environment and human needs and interest [39], [44]. Environmental sustainability is based on four basic parts: atmosphere, biosphere, hydrosphere, and lithosphere. The atmosphere covers air and noise pollution, and the maximum weightage of the atmosphere is 200 (100 for air pollution and 100 for noise pollution). The biosphere consists of biodiversity loss (maximum weightage 100), as the livestock is dependent on trees and the Rohiro trees are banned in operational areas, which threatened the gugrall (Camiphera Mukul), phoge (Clligonum polygonoides), rohiro (Tecoma undulate), Peeloo (Salvadora persica), Kandi (Prosopis cineraria), and Kombhat (Acacia Senegal) species. The hydrosphere is related to water sustainability, which has 100 maximum weightages for this research. The lithosphere is the crust and mental shell of earth and abbreviated with $\mathrm{L}$ in the model. The soil erosion, above and underground interferences, and aesthetic degradation cover under the lithospheric part of the environment with a maximum of 400 weights. The second part of the division depends on human needs and interests with 300 weights. The areas covered under human needs and interests are human health and safety, social interaction and quality of life, and economy.

Table 5. Determination of sustainability (S) components.

\begin{tabular}{|c|c|c|}
\hline & Components of Environment (E) & Maximum Possible Scores for $\mathrm{E}$ and $\mathrm{H}_{\mathrm{NI}}$ \\
\hline $\mathrm{A}_{1}$ & Air Pollution & \multirow{2}{*}{$A \max =2 \times 100=200$} \\
\hline $\mathrm{A}_{2}$ & Noise Pollution & \\
\hline $\mathrm{B}_{1}$ & Biodiversity Loss & $\mathrm{B} \max =1 \times 100=100$ \\
\hline $\mathrm{H}_{1}$ & Water Pollution & $\mathrm{H} \max =1 \times 100=100$ \\
\hline $\mathrm{L}_{1}$ & Soil Erosion & \multirow{4}{*}{$\mathrm{L} \max =4 \times 100=400$} \\
\hline $\mathrm{L}_{2}$ & Above-Ground Interferences & \\
\hline $\mathrm{L}_{3}$ & Underground Interferences & \\
\hline $\mathrm{L}_{4}$ & Aesthetic Degradation & \\
\hline \multicolumn{3}{|c|}{ Components of $\mathrm{H}_{\mathrm{NI}}$} \\
\hline $\mathrm{H}_{\mathrm{NI}} 1$ & Human Health and Safety & \multirow{3}{*}{$\mathrm{H}_{\mathrm{NI}} \max =3 \times 100=300$} \\
\hline $\mathrm{H}_{\mathrm{NI}} 2$ & Social Interaction and Quality of Life & \\
\hline $\mathrm{H}_{\mathrm{NI}} 3$ & Economy & \\
\hline \multicolumn{3}{|c|}{ Evaluation of Sustainability for Sindh Engro Coal Mining } \\
\hline \multicolumn{3}{|c|}{$\mathrm{S}=\mathrm{E}-\mathrm{H}_{\mathrm{NI}}$} \\
\hline
\end{tabular}

Table 6 shows the final results of environmental sustainability. The first column contains the actual score of environments. In contrast, the second column includes a number of human needs and interests. The third column shows sustainability values with 
a negative sign. The negative sign of sustainability amount declared that the Sindgh Engro coal mines negatively influenced the environment.

$$
\begin{aligned}
& \mathrm{E}=\frac{\left[\left(\sum \mathrm{A}_{\max }-\sum \mathrm{A}\right)+\left(\sum \mathrm{B}_{\max }-\sum \mathrm{B}\right)+\left(\sum \mathrm{H}_{\max }-\sum \mathrm{H}\right)+\left(\sum \mathrm{L}_{\max }-\sum \mathrm{L}\right)\right]}{\sum \mathrm{A}_{\max }+\sum \mathrm{B}_{\max }+\sum \mathrm{H}_{\max }+\sum \mathrm{L}_{\max }} \\
& \mathrm{E}=\frac{\left[\left(\sum \mathrm{A}_{\max }-\left(\mathrm{A}_{1}+\mathrm{A}_{2}\right)+\left(\sum \mathrm{B}_{\max }-\sum \mathrm{B}\right)+\left(\sum \mathrm{H}_{\max }-\sum \mathrm{H}\right)+\left(\sum \mathrm{L}_{\max }-\left(\mathrm{L}_{1}+\mathrm{L}_{2}+\mathrm{L}_{3}+\mathrm{L}_{4}\right)\right]\right.\right.}{\sum \mathrm{A}_{\max }+\sum \mathrm{B}_{\max }+\sum \mathrm{H}_{\max }+\sum \mathrm{L}_{\max }} \\
& \mathrm{E}=\frac{[(200-(100+76)+(100-88.83)+(100-86.58)+(400-(75.71+86.66+86.67+76.41)]}{200+100+100+400} \\
& \mathrm{E}=\frac{[(200-(176)+(11.17)+(13.42)+(400-(325.45)]}{800} \\
& \mathrm{E}=\frac{(24+11.17+13.42+74.55)}{800} \\
& \mathrm{E}=\frac{123.14}{800} \\
& \mathrm{E}=0.153925 \\
& \mathrm{H}_{\mathrm{NI}}=\frac{\left(\mathrm{H}_{\mathrm{NI} 1}+\mathrm{H}_{\mathrm{NI} 2}\right)+\left(\mathrm{H}_{\mathrm{N} 33 \max }-\mathrm{H}_{\mathrm{NI} 3} \text { actual }\right)}{\sum \mathrm{H}_{\mathrm{NImax}}} \\
& \mathrm{H}_{\mathrm{NI}}=\frac{(86.8+83.16)+(100-43.34)}{300} \\
& \mathrm{H}_{\mathrm{NI}}=\frac{169.96+56.66}{300} \\
& \mathrm{H}_{\mathrm{NI}}=\frac{226.62}{300} \\
& \mathrm{H}_{\mathrm{NI}}=0.7554 \\
& \mathrm{~S}=\mathrm{E}-\mathrm{H}_{\mathrm{NI}} \\
& \mathrm{S}=0.153925-0.7554 \\
& S=-0.601475 \\
& \mathrm{E}>\mathrm{H}_{\mathrm{NI}}=\text { Sustainable relation; } \mathrm{E} \leq \mathrm{H}_{\mathrm{NI}}=\mathrm{un}-\text { sustainable relation } \\
& E(0.153925)<\mathrm{H}_{\mathrm{NI}}(0.7554)=\text { un }- \text { Sustainable }
\end{aligned}
$$

Table 6. Environmental sustainability.

\begin{tabular}{ccccc}
\hline Mine & E & $\mathbf{H}_{\mathrm{NI}}$ & S-Value & S-Level \\
\hline $\begin{array}{l}\text { Sindh Engro } \\
\text { Coal Mining }\end{array}$ & 0.153925 & 0.7554 & -0.601475 & Strong \\
\hline
\end{tabular}

Environmental sustainability and Sindh Engro Coal mining by employing the Phillips model are displayed in Table 6 . The environment (E) value is 0.153925 , and the value of human need and interest $\left(\mathrm{H}_{\mathrm{NI}}\right)$ is 0.7554 . Therefore, as per the sustainability check, the human needs and interest value is more significant than environment $\mathrm{E}(\mathrm{t})<\mathrm{H}_{\mathrm{NI}}(\mathrm{t}) \Leftrightarrow$ $\mathrm{S}(\mathrm{t})<0$. Thus, an unsustainable relation between the environment and coal mining is confirmed, or we can say that Sindh Engro coal mining negatively influences environmental sustainability $[12,13,40,45,46]$.

\section{Discussion}

The analytical part of this study is based on two sections: a qualitative part (Folchi method) and quantitative part (Phillips Environmental Sustainability Mathematics (PESM) Model). Due to a combination of qualitative and quantitative features, this research confirmed its semi-quantitative quality. The Folchi method covered almost all environment influenced factors as per four significant spheres of environment. Table 1 presents all possible coal mining environments and impacting factors specification. Table 2 contains the numbering according to the intensity of influencing factors for the indexing process. This table also explains the measuring scale of the individual factor for the convenience of readers. Table 3 is most important to understand for interlinking after and before processes. 
Table 3 is technically maintained with possible maximum, medium, and minimum points by Folchi. Finally, Table 4 presents the multiplication results.

The aggregate scores of an individual factor in Table 4 declare the actual contribution of these factors in the environment for the Sindh Engro coalfield. The second part shows the result of the Phillips Environmental Sustainability Mathematics (PESM) Model. The expected scores and actual scores are put in the Phillips Environmental Sustainability Mathematics formula. Figure 4 describes the sustainable or unsustainable contribution of coal mining to environmental sustainability. As per our analysis, the environmental contribution is less than human needs and interests. The Sindh Engro coal mines confirmed an unsustainable relationship with the environment. The Sindh Engro coal mines have the largest deposit of coal and explore coal with foreign collaboration. Due to foreign association to digging coal, this coalfield utilized well-developed technology to explore the coal deposits. The unsustainable environmental contribution can ease the way to explore less developed coal mines and eradicate the emissions-friendly resources that will enable the sustainable contribution in the environment and economy.

\section{Conclusions}

The contribution of coal mining to economic development cannot be denied, but its source of environmental pollution, socio-economic issues, soil erosion, and ecological destruction. In the current study, the Folchi weightage of influencing determinants identifies environmental factors' intensity and contribution. The suitable assessment process is the basis of accurate results and understating the direction of mining impacts. The adversity of environmental determinants is recognized at the planning stage and set the corrective measures. The various coal mining operational and post-operational activities are destroying the environment's sustainability. The correlation matrix is generated by employing the Folchi method, and the final values of the Folchi method are used in Phillips Environmental Sustainability Mathematics (PESM) Model. The research confirms an unsustainable relation between the environment and Sindh Engro coal mining $\left(\mathrm{E} \leq \mathrm{H}_{\mathrm{NI}}=\right.$ unsustainable relation). Coal mining is increasing water pollution, air pollution, and noise pollution. The underground and above-ground resources face the problem of toxicities. Soil erosion, soil degradation, and soil loss are also going upward due to insalubrious coal mining operations.

The worker's health and safety are entirely ignored in the mining process, and no training sessions are held for new recruiters. As a result, the life of biodiversity is threatened by coal mining in the Thar Desert. The health and safety awareness among workers is poor and becomes the reason for causalities, fatalities, and accidents. The direct discharge of wastages can resolve thar effluents from all blocks into Left Bank Outfall Drain (LBOD) instead of new ponds construction. The studies should analyze the direct and indirect impact of saline water storage, contaminant/solute transport, and evaporation.

The salt concentration tolerance should be checked to utilize dewatered water for biosaline agriculture and marked salt-tolerant crops and others. Environmental sustainability and biodiversity can be protected by expanding the irrigated agriculture area. Greenhouse cultivation should be promoted because it could reduce the metal-ingestion-associated health risks from edible vegetable biomass and the soil to plant bioaccumulation (BCF). By the higher level of soil organic matters and faster growth rate, the greenhouse cultivation metal uptake rate is less than open fields. Therefore, greenhouse cultivation can provide less contaminated organic food for residents in adverse polluted areas.

The aquatic habitats can be saved by promoting aqua farming at Gordano dam/pond. The extracted groundwater from mines can be transformed into drinking water by Reverse Osmosis (RO). This transformation can reduce the inflow of water into the Gordano dam/pond. The local worker should prioritize job opportunities in the Thar coalfield compared to foreigners. The landholders of Thar who lost their earning due to the construction of coal plants should be considered for mining jobs and projects. The planting of trees, shrubs, and grass should be encouraged along the roadsides and Gordano dam/pond 
embankments. The planting can reduce wind erosion and silting of the pond, while the local environment will be better. Supercritical and ultra-supercritical coal-fired power plants should minimize gas emissions, i.e., carbon dioxide, sulfur, and mercury, in the firing process. The diminishing rate of toxic gases emission will increase environmental sustainability and decrease fuel costs per megawatt.

This research enlightened the influencing factor of environmental sustainability during the exploration of the coal deposit. Being a developing country, Pakistan is using old methods of coal mining. The environmentalists have expressed their concerns about greenhouse gas reduction and stated that zero greenhouse gas is required within three decades. Practitioners can obscure the problems of irrationalities, less technological development, political instability, and injustices of extraction projects. The specific location of the Sindh Engro coal mines is a developing place, and more specifically, the people of that area are not financially strong. The poor population is focused on getting basic needs and avoiding environmental sustainability policies. The status of residents' lives can be raised by increasing the employment level and sustainable environment awareness. The adoption of green technology during mining exploration can eradicate emissions and positively contribute to environmental sustainability. Developed technology also helps obtain pure refined coal as compared to raw coal. Raw coal emits more carbon dioxide than refined coal. The mining industry management should follow the local and global sustainable environmental policies. As per our findings, the local employment is very low in the Sindh Engro coal mine residents.

Author Contributions: Conceptualization, M.M., S.N.; methodology, M.S., L.I.; investigation, Q.Z.; resources, M.S.; writing—original draft preparation, M.S., L.I.; writing—review and editing, M.S., M.M., Q.Z., S.N.; visualization, M.M.; supervision, M.S., L.I., and S.N.; project administration, M.M. All authors have read and agreed to the published version of the manuscript.

Funding: No external funding is received for this research.

Institutional Review Board Statement: Not applicable.

Informed Consent Statement: Not applicable.

Data Availability Statement: Data are personally collected by structure format of Folchi from the high authorities as well as workers of Sindh engro coal mine.

Acknowledgments: This work is supported by the construct program of applied characteristic discipline "Applied Economics" Hunan Province.

Conflicts of Interest: The authors declare no conflict of interest.

\section{References}

1. Ohara, T.; Akimoto, H.; Kurokawa, J.; Horii, N.; Yamaji, K.; Yan, X.; Hayasaka, T. An Asian emission inventory of anthropogenic emission sources for the period 1980-2020. Atmos. Chem. Phys. 2007, 7, 4419-4444. [CrossRef]

2. Lu, Y.; Wang, Q.; Zhang, X.; Qian, Y.; Qian, X. China's black carbon emission from fossil fuel consumption in 2015, 2020, and 2030. Atmos. Environ. 2019, 212, 201-207. [CrossRef]

3. Lin, B.; Raza, M.Y. Coal and economic development in Pakistan: A necessity of energy source. Energy 2020, 207, 118244. [CrossRef]

4. Kousar, S.; Rehman, A.; Zafar, M.; Ali, K.; Nasir, N. China-Pakistan Economic Corridor: A gateway to sustainable economic development. Int. J. Soc. Econ. 2018, 45, 909-924. [CrossRef]

5. Farooqui, M.A.; Aftab, S.M. China-Pakistan Economic Corridor; Prospects and Challenges for Balochistan, Pakistan. IOP Conf. Ser. Mater. Sci. Eng. 2018, 414, 012046. [CrossRef]

6. Skoczkowski, T.; Bielecki, S.; Kochański, M.; Korczak, K. Climate-change induced uncertainties, risks and opportunities for the coal-based region of Silesia: Stakeholders' perspectives. Environ. Innov. Soc. Transit. 2020, 35, 460-481. [CrossRef]

7. Watts, J. We Have 12 Years to Limit Climate Change Catastrophe, Warns UN. The Guardian. 2018, p. 8. Available online: https:// www.theguardian.com/environment/2018/oct/08/global-warming-must-not-exceed-15c-warns-landmark-un-report (accessed on 16 November 2020).

8. Burke, A.; Fishel, S. A coal elimination treaty 2030: Fast tracking climate change mitigation, global health and security. Earth Syst. Gov. 2020, 3, 100046. [CrossRef]

9. Sohoo, I.; Ritzkowski, M.; Kuchta, K.; Cinar, S.Ö. Environmental Sustainability Enhancement of Waste Disposal Sites in Developing Countries through Controlling Greenhouse Gas Emissions. Sustainability 2020, 13, 151. [CrossRef] 
10. Rashid, M.I.; Benhelal, E.; Rafiq, S. Reduction of greenhouse gas emissions from gas, oil, and coal power plants in Pakistan by carbon capture and storage (CCS): A Review. Chem. Eng. Technol. 2020, 43, 2140-2148. [CrossRef]

11. Shen, M.; Huang, W.; Chen, M.; Song, B.; Zeng, G.; Zhang, Y. (Micro) plastic crisis: Un-ignorable contribution to global greenhouse gas emissions and climate change. J. Clean. Prod. 2020, 254, 120138. [CrossRef]

12. Mohsin, M.; Naseem, S.; Zia-ur-Rehman, M.; Baig, S.A.; Salamat, S. The crypto-trade volume, GDP, energy use, and environmental degradation sustainability: An analysis of the top 20 crypto-trader countries. Int. J. Financ. Econ. 2020. [CrossRef]

13. Sarfraz, M.; Mohsin, M.; Naseem, S.; Kumar, A. Modeling the relationship between carbon emissions and environmental sustainability during COVID-19: A new evidence from asymmetric ARDL cointegration approach. Environ. Dev. Sustain. 2021, 1-19. [CrossRef]

14. Ghose, M.K.; Majee, S.R. Assessment of the impact on the air environment due to opencast coal mining-An Indian case study. Atmos. Environ. 2000, 34, 2791-2796. [CrossRef]

15. Ahmad, A.; Hakimi, M.H.; Chaudhry, M.N. Geochemical and organic petrographic characteristics of low-rank coals from Thar coalfield in the Sindh Province, Pakistan. Arab. J. Geosci. 2014, 8, 5023-5038. [CrossRef]

16. Sanjrani, M.A.; Memon, I.H.; Awan, B.A. Environmental Impact of Lakhra Coal Mining, Sindh province, Pakistan. N. Am. Acad. Res. 2018, 1, 72-75.

17. Cao, C.; Chen, X.-P.; Ma, Z.-B.; Jia, H.-H.; Wang, J.-J. Greenhouse cultivation mitigates metal-ingestion-associated health risks from vegetables in wastewater-irrigated agroecosystems. Sci. Total. Environ. 2016, 560-561, 204-211. [CrossRef]

18. Hussain, M.; Muhammad, S.; Malik, R.N.; Khan, M.U.; Farooq, U. Status of heavy metal residues in fish species of Pakistan. Rev. Environ. Contam. Toxicol. Vol. 2014, 230, 111-132. [CrossRef]

19. Obiora, S.C.; Chukwu, A.; Davies, T.C. Heavy metals and health risk assessment of arable soils and food crops around $\mathrm{Pb}-\mathrm{Zn}$ mining localities in Enyigba, southeastern Nigeria. J. Afr. Earth Sci. 2016, 116, 182-189. [CrossRef]

20. Zheng, N.; Wang, Q.; Zhang, X.; Zheng, D.; Zhang, Z.; Zhang, S. Population health risk due to dietary intake of heavy metals in the industrial area of Huludao city, China. Sci. Total. Environ. 2007, 387, 96-104. [CrossRef]

21. Khan, A.A.; Khan, W.A.; Chaudhry, A.A. Mammalian diversity in thar desert habitat of tharparkar district, Sindh, Pakistan. Pak. J. Zool. 2015, 47, 1205-1211.

22. Masih, A. Thar Coalfield: Sustainable Development and an Open Sesame to the energy security of Pakistan. J. Phys. Conf. Ser. 2018, 989, 012004. [CrossRef]

23. Ansari, K.A.; Mahar, A.R.; Malik, A.R.; Sirohi, M.H.; Saand, M.A.; Simair, A.A.; Mirbahar, A.A. Impact of grazing on plant biodiversity of desert area of district Khairpur, Sindh, Pakistan. J. Anim. Plant Sci. 2017, 27, 1931-1940.

24. Zaigham, N.A.; Ahmad, M.; Hisam, N. Thar rift and its significance for hydrocarbons. In Pakistan Association of Petroleum Geoscientists (PAPG), Islamabad Google Scholar; Pakistan Association of Petroleum Geoscientists: Islamabad, Pakistan, 2000.

25. Zaigham, N.A.; Nayyar, Z.A. Renewable hot dry rock geothermal energy source and its potential in Pakistan. Renew. Sustain. Energy Rev. 2010, 14, 1124-1129. [CrossRef]

26. Phuong, T.T.; Shrestha, R.P.; Chuong, H.V. Simulation of soil erosion risk in the upstream area of Bo River watershed. In Redefining Diversity E Dynamics of Natural Resources Management in Asia; Elsevier: Amsterdam, The Netherlands, 2017; Volume 3, pp. 87-99.

27. Dondini, M.; Abdalla, M.; Aini, F.K.; Albanito, F.; Beckert, M.R.; Begum, K.; Brand, A.; Cheng, K.; Comeau, L.-P.; Jones, E.O. Projecting soil C under future climate and land-use scenarios (modeling). In Soil Carbon Storage; Elsevier: Amsterdam, The Netherlands, 2018; pp. 281-309.

28. Widanarko, B.; Legg, S.; Stevenson, M.; Devereux, J.; Jones, G. Prevalence of low back symptoms and its consequences in relation to occupational group. Am. J. Ind. Med. 2013, 56, 576-589. [CrossRef]

29. Vearrier, D.; Greenberg, M.I. Occupational health of miners at altitude: Adverse health effects, toxic exposures, pre-placement screening, acclimatization, and worker surveillance. Clin. Toxicol. 2011, 49, 629-640. [CrossRef]

30. Viljoen, D.A.; Nie, V.; Guest, M. Is there a risk to safety when working in the New South Wales underground coal-mining industry while having binaural noise-induced hearing loss? Intern. Med. J. 2006, 36, 180-184. [CrossRef]

31. Md-Nor, Z.; Kecojevic, V.; Komljenovic, D.; Groves, W. Risk assessment for loader-and dozer-related fatal incidents in US mining Int. J. Inj. Contr. Saf. Promot. 2008, 15, 65-75. [CrossRef]

32. Paul, P.S.; Maiti, J. The role of behavioral factors on safety management in underground mines. Saf. Sci. 2007, 45, 449-471. [CrossRef]

33. Panhwar, S.; Mahar, R.B.; Abro, A.A.; Ijaz, M.W.; Solangi, G.S.; Muqeet, M. Health and safety assessment in Lakhra coal mines and its mitigation measures. Iran. J. Heal. Saf. Environ. 2017, 4, 775-780.

34. Brnich, M.J.; Kowalski-Trakofler, K.M.; Brune, J. Underground Coal Mine Disasters 1900-2010: Events, Responses, and a Look to the Future. Extr. Sci. Century Min. Res. 2010, 363. Available online: https:/ /www.cdc.gov/NIOSH/Mining/UserFiles/works/ pdfs/ucmdn.pdf (accessed on 26 December 2020).

35. Grayson, R.L.; Kinilakodi, H.; Kecojevic, V. Pilot sample risk analysis for underground coal mine fires and explosions using MSHA citation data. Saf. Sci. 2009, 47, 1371-1378. [CrossRef]

36. Naseem, S.; Fu, G.L.; Mohsin, M.; Rehman, M.Z.; Baig, S.A. Semi-Quantitative Environmental Impact Assessment of Khewra Salt Mine of Pakistan: An Application of Mathematical Approach of Environmental Sustainability. Min. Met. Explor. 2020, $37,1-12$. [CrossRef] 
37. Phillips, J. Applying a mathematical model of sustainability to the Rapid Impact Assessment Matrix evaluation of the coal mining tailings dumps in the Jiului Valley, Romania. Resour. Conserv. Recycl. 2012, 63, 17-25. [CrossRef]

38. Folchi, R. Environmental impact statement for mining with explosives: A quantitative method. Proc. Annu. Conf. Explos. Blasting Tech. 2003, 2, 285-296.

39. Phillips, J. Using a mathematical model to assess the sustainability of proposed bauxite mining in Andhra Pradesh, India from a quantitative-based environmental impact assessment. Environ. Earth Sci. 2012, 67, 1587-1603. [CrossRef]

40. Phillips, J. A mathematical model of sustainable development using ideas of coupled environment-human systems (Invited Article). Pelican Web J. Sustain. Dev. 2010, 6, 127-142.

41. Kholod, N.; Evans, M.; Pilcher, R.C.; Roshchanka, V.; Ruiz, F.; Coté, M.; Collings, R. Global methane emissions from coal mining to continue growing even with declining coal production. J. Clean. Prod. 2020, 256, 120489. [CrossRef]

42. Oei, P.-Y.; Brauers, H.; Herpich, P. Lessons from Germany's hard coal mining phase-out: Policies and transition from 1950 to 2018. Clim. Policy 2019, 20, 963-979. [CrossRef]

43. Jakob, M.; Steckel, J.C.; Jotzo, F.; Sovacool, B.K.; Cornelsen, L.; Chandra, R.; Edenhofer, O.; Holden, C.; Löschel, A.; Nace, T.; et al. The future of coal in a carbon-constrained climate. Nat. Clim. Chang. 2020, 10, 704-707. [CrossRef]

44. Azapagic, A. Developing a framework for sustainable development indicators for the mining and minerals industry. J. Clean. Prod. 2004, 12, 639-662. [CrossRef]

45. Rawat, N.S. A study of physicochemical characteristics of respirable dust in an Indian coal mine. Sci. Total Environ. 1982, 23, 47-54. [CrossRef]

46. Tiwary, R.K. Environmental impact of coal mining on water regime and its management. Water Air Soil Pollut. 2001, 132, 185-199. [CrossRef] 